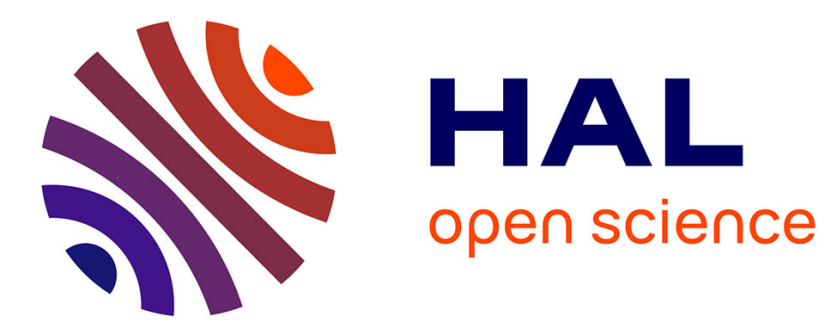

\title{
Magmas trapped at the continental lithosphere-asthenosphere boundary
}

C. Crépisson, Guillaume Morard, H. Bureau, Gaëlle Prouteau, Yann Morizet, S. Petitgirard, C. Sanloup

\section{- To cite this version:}

C. Crépisson, Guillaume Morard, H. Bureau, Gaëlle Prouteau, Yann Morizet, et al.. Magmas trapped at the continental lithosphere-asthenosphere boundary. Earth and Planetary Science Letters, 2014, 393, pp.105 - 112. 10.1016/j.epsl.2014.02.048 . hal-00959932

\section{HAL Id: hal-00959932 \\ https://hal.science/hal-00959932}

Submitted on 17 Mar 2014

HAL is a multi-disciplinary open access archive for the deposit and dissemination of scientific research documents, whether they are published or not. The documents may come from teaching and research institutions in France or abroad, or from public or private research centers.
L'archive ouverte pluridisciplinaire HAL, est destinée au dépôt et à la diffusion de documents scientifiques de niveau recherche, publiés ou non, émanant des établissements d'enseignement et de recherche français ou étrangers, des laboratoires publics ou privés. 


\section{Magmas trapped at the continental lithosphere-asthenosphere

(1) \\ ${ }^{b}$ Sorbonne Universités, UPMC Univ Paris 06, UMR-CNRS 7590, IMPMC, F-75005, Paris, France \\ ${ }^{c}$ ISTO, Orléans, France \\ ${ }^{d}$ Université de Nantes, UMR-CNRS 6112, LPGN, France \\ ${ }^{e}$ European Synchrotron Radiation Facility, Grenoble, France \\ ${ }^{f} C S E C$ and School of Physics and Astronomy, University of Edinburgh, UK}

\section{Abstract}

The lithosphere-asthenosphere boundary (LAB) beneath the continents is a key interface in plate tectonics, yet its nature remains elusive. A partial melt layer has been advocated to explain its geophysical characteristics. However, the main counter-argument is that such a layer can not be stable as melts should rise through the lithosphere. Density measurements of volatile-containing alkali basalts taken as a proxy for LAB melts show that they are neutrally buoyant at the pressure $(\mathrm{P})$ temperature $(\mathrm{T})$ conditions of the LAB under continents. Complementary X-ray diffraction and Raman data provide structural insights on melt compaction mechanisms. Basalts generated below the lithosphere may thus be gravitationally trapped and accumulate over time. Their presence provide answers to key questions on continental lithosphere geodynamics, and in particular on cratonic keels stability. This buoyancy trap would cease to exist at higher mantle $\mathrm{T}$ such as those relevant of the Archean, and as such, could be linked to the onset of plate tectonics.

Preprintsesponding awthrevier

Email addresses: celine.crepisson@ens. fr (C. Crépisson),

January 28, 2014 chrystele.sanloupded.ac.uk (C. Sanloup) 
Keywords: molten basalts, density, structure, asthenosphere, cratons

\section{Introduction}

Several geophysical observables define the continental LAB: 1) the Lehmann discontinuity at constant depth $(200-250 \mathrm{~km})$ across the Archean and proterozoic units in North America (Yu and Romanowicz, 2010); 2) the low velocity zone in global tomographic models of shear-wave velocity (Cammarano and Romanowicz, 2007); 3) a shear wave radial anisotropy with horizontally polarized shear waves traveling faster than those that are vertically polarized, anomaly present under most cratons in the depth range 250-400 km (Yu and Romanowicz, 2010) with EastWest flow in the convective mantle, and North-South fast direction in the LAB; 4) an electrical resistivity drop (Jones, 1999; Jones et al., 2010). Only observable 2 is common to oceanic and continental LAB, the former being significantly shallower (circa $90 \mathrm{~km}$ ). It has long been suggested that all characteristics given above for the continental LAB may be caused by small amounts of partial melt (Eaton et al., 2009; Anderson and Sammis, 1970). Petrological models of the continental lithosphere describe its lowest part as enriched by melts from below (Foley, 2008), consistently with melts having ponded in the asthenosphere (O'Reilly and Griffin, 2010). Magnetotelluric observations suggest that the partial melt layer is of finite thickness, which implies that partial melting ceases at greater depths (Jones, 1999), and/or that melts are trapped at this particular depth as suggested by Agee (1998) and Chen et al. (2002). A stable partial melt layer in the LAB would have major geodynamical consequences such as lithosphere-asthenosphere decoupling 
(Doglioni et al., 2011) and explain why cratonic roots survive so long while numerical models predict that they should be eroded (King, 2005) by shielding them from the mantle stress field. However, this suggestion requires the presence of materials that will: 1) melt at the P-T conditions of the LAB, and 2) be retained at that depth by some mechanism.

\section{Why the choice of an alkali basalt?}

There has been a strong focus on carbonatites as candidates for LAB melts, essentially as they can be generated as deep as $250 \mathrm{~km}$ from partial melting of carbonated peridotite, and have been proposed to explain the oceanic low-velocity zone (Gaillard et al., 2008; Dasgupta et al., 2013). However, their low density (2.2$2.3 \mathrm{~g} / \mathrm{cc}$ ) discards them for the continental LAB as they would not be retained at depth. Instead, alkali basalts combine a higher density with a relatively low melting point. The solidus of an alkali basalt is lower than that of a typical mid-ocean ridge basalt (MORB) at depth with a maximum depression of $200 \mathrm{~K}$ at $6 \mathrm{GPa}$ (Tsuruta and Takahashi, 1998), and in contrast to the MORB solidus, the alkali basalt solidus becomes very steep around 6-7 GPa (Fig.1), i.e. at or around the conditions of the continental LAB.

Alkali basalts have been dragged in the Japanese sea and interpreted as originating from the asthenosphere (Hirano et al., 2006), with a high vesicularity suggesting high $\mathrm{CO}_{2}$ content in the pre-eruptive melt. The contribution of high pressure eclogites, the crystallized high pressure equivalent of an alkali basalt, to the source of mafic magmatism has been recognized from the isotopic and geochemi- 
cal characteristics of some basalts, in particular of ocean island basalts (Hofmann, 2003; Pertermann and Hirschmann, 2003; Sobolev et al., 2005, 2007). The importance of volatile-rich alkali basalts in the asthenosphere may however not be limited to the oceanic contexts. Silica enrichment of some cratonic peridotites compared to what would be expected for simple partial melt residues (Carlson et al., 2005) has been interpreted by percolation of Si-rich melts derived from subducted slabs (Rudnick et al., 1994; Kelemen et al., 1998). Similarly, eclogitic melts may have lead to the refertilisation of the lithosphere at depths of circa $170-220 \mathrm{~km}$ beneath cratons (O'Reilly and Griffin, 2010). Finally, diamond inclusions originating from the asthenosphere are of metabasite (i.e. eclogitic) affinity (Harte, 2010), and the genesis of diamondites, polycristalline diamonds, has been linked to the presence of volatile saturated eclogitic melts in the sub-cratonic mantle (Mikhail et al., 2013).

The presence of eclogite in the cratonic mantle as a whole has been quantified from seismology to about $1 \%$, and locally to as much as $15 \%$ (Schultze, 1989), as mafic magmatic rocks may be returned to the mantle via plate subduction or through delamination of the lower crust after contributing to the formation of cratonic roots (Lee, 2006). This motivated the investigation of the eclogite dry solidus up to $5 \mathrm{GPa}$ (Spandler et al., 2008). The composition used in this study, a primary alkali basalt (Pichavant et al., 2009), contains $1.5 \mathrm{wt} \%$ more $\mathrm{K}_{2} \mathrm{O}$ than the GA2 composition used by Spandler et al. (2008). The eclogite dry solidus can be depressed by circa $250 \mathrm{~K}$ for our alkali- and volatile-rich composition $\left(0.9 \mathrm{wt} \% \mathrm{CO}_{2}\right.$ 1.04 wt $\% \mathrm{H}_{2} \mathrm{O}$ ), accounting for the effect of dissolved carbonate ions and water observed on altered MORB at high pressure - respectively circa $-25 \mathrm{~K}$ per wt\% 
$\mathrm{CO}_{2}$ (Gerbode and Dasgupta, 2010) and $-150 \mathrm{~K}$ for $0.87 \mathrm{wt} \% \mathrm{H}_{2} \mathrm{O}$ in the glass (Kiseeva et al., 2012) - and for the effect of excess $\mathrm{K}_{2} \mathrm{O}$ assuming a similar effect to that observed for a hydrated and carbonated peridotite in the 4-6 GPa range (Foley et al., 2009). T estimates at the LAB under cratons range from $1573 \mathrm{~K}$ to $1773 \mathrm{~K}$ at $200 \mathrm{~km}$ ( $\sim 6.6 \mathrm{GPa})$ from the study of xenoliths in the Kaapvaal craton in South Africa (James et al., 2004). The solidus of our composition will thus be about $200 \mathrm{~K}$ below petrological $\mathrm{T}$ estimates for the $\mathrm{LAB}$, which corresponds to $70-85 \%$ of melt fraction (Pertermann and Hirschmann, 2003; Spandler et al., 2008) as required to generate an alkali basaltic melt. Consistently, a melt with a similar composition to ours was obtained by bringing an eclogite $+3 \mathrm{wt} \%\left(\mathrm{H}_{2} \mathrm{O}-\mathrm{CO}_{2}\right)+3 \mathrm{wt} \% \mathrm{KCl}$ at $5 \mathrm{GPa}$ and $1573 \mathrm{~K}$ (Butvina et al., 2009). The high alkali content is thus efficient in both lowering the melting point and increasing melt productivity, and it is important in that respect that alkalis are not leached out of the subducted slabs, as supported by examination of eclogites from paleo-subduction zones (Spandler et al., 2004).

A few studies have investigated the reactivity of eclogite-derived melts with peridotite, some finding that all melt is consumed (Yaxley and Green, 1998), others that once a reaction band of pyroxene is produced, it will prevent further contact between melt and mantle, thereby trapping melt in peridotite/pyroxenite reaction zones (Kogiso et al., 2004). Latest reaction experiments between peridotite (KLB1) and MORB-eclogite-derived carbonated melts $\left(2.6 \mathrm{wt} \% \mathrm{CO}_{2}\right)$ (Malik and Dasgupta, 2013) produced between 11 and $24 \%$ sustainable melt at near equilibrium conditions, while melt composition spanned the range of most alkali basalts. Malik 
and Dasgupta (2013) noted that their experiments are relevant beneath continental lithosphere as generation of the first carbonated-eclogite melt might be triggered by conversion of graphite to carbonate at the redox front, constrained to occur at $250 \mathrm{~km}$ depth (Rohrbach et al., 2007, 2011).

Volatile-containing alkali basalts can thus thermally be present in the LAB but the physical mechanism for retention is still to be discovered as magmas are expected to percolate through the silicate matrix after formation. Wetting experiments at high $\mathrm{P}$ suggest that, in contrast to low $\mathrm{P}$ conditions, very little amounts are needed for the melt to totally wet olivine crystals and hence have a large influence on the electrical conductivity of the upper mantle (Yoshino et al., 2009). But another consequence of this high melt connectivity is that it will be even harder to prevent it from moving through the mantle. An alternative to mechanical retention of melts at depth is gravitational trapping. This idea was suggested (Agee, 1998) based on shock-wave density data on basalts (Rowan, 1993). However, the scatter in the shock-wave data was too large to be conclusive and an ex situ sink-float density measurement on molten MORB at $6 \mathrm{GPa}$ did not confirm it either (Agee, 1998). Additional sink-float data have been collected on molten MORB with and without water in the $15-20 \mathrm{GPa} / 2573 \mathrm{~K}-2673 \mathrm{~K}$ range (Sakamaki et al., 2006), but these conditions are largely above the estimates for the LAB discussed above, especially for $\mathrm{T}$, and that makes extrapolations back difficult. 


\section{Experimental procedures}

\subsection{Generation of high P-T conditions}

High pressure conditions were generated by a VX5 Paris-Edinburgh press. The cell-assembly used is detailed in Van Kan Parker et al. (2010); it consists in a 7/2.4 mm boron epoxy gasket, a graphite heater and an hBN pressure transmitting medium, while P-T conditions are derived from the cell volumes of internal calibrants, $\mathrm{hBN}$ and $\mathrm{Pt}(\mathrm{Pt}$ ribbon inserted between $\mathrm{hBN}$ and the sample capsule). Estimated error bars are $\pm 0.25 \mathrm{GPa}$ on $\mathrm{P}$, and $\pm 50 \mathrm{~K}$ on $\mathrm{T}$. The starting composition (Table 1) used in this work had been previously synthesized at ISTO (Pichavant et al., 2009). Sample was hand-packed in a single crystal diamond capsule and covered by Pt-10\%Rh caps. Single crystal diamond is the best capsule material for these experiments as it provides the lowest absorption back-ground possible and hence considerably reduces the error bar on the density measurements, and it preserves a cylindrical shape upon compression. Last but not least, diamond is the stable phase of carbon at the P-T-oxygen fugacity conditions of the continental LAB. The diamond capsules were $1.5 \mathrm{~mm}$ in height and either $1.0 \mathrm{~mm}$ inner diameter (6.25 GPa run) or $0.75 \mathrm{~mm}$ inner diameter (3.9 GPa run). P transmission to the sample inside the rigid diamond capsule is fully achieved for T above $1200 \mathrm{~K}$, as demonstrated by calibration experiments (Van Kan Parker et al., 2010).

\subsection{Ex situ chemical, Raman and IR measurements}

The sample recovered from the $6.25 \mathrm{GPa}$ run was lost upon extraction from the diamond capsule. The analyses reported here for this pressure point (Table 
1) were done on a sample synthesized ex situ using a Paris-Edinburgh press at IMPMC with the same cell-assembly and ran for 40 minutes at identical power and oil pressure conditions. Chemical analyses were done using a Cameca SX100 electron microprobe at the EMMAC centre, University of Edinburgh. Conditions were $15 \mathrm{keV}$ and $4 \mathrm{nA}$ current for analysis of $\mathrm{Ca}$ and $\mathrm{Na}$, and $15 \mathrm{keV}$ and 40 nA current for all other elements. We used a $20 \mu \mathrm{m}$ beam size for glass analyses and a $8 \mu \mathrm{m}$ beam size for crystals analyses. For both samples, the glass is very homogeneous (Table 1), and crystals are sedimented at the bottom of the capsule (Fig.2). Pyroxene crystals are observed in both runs, with a small addition of garnet at $6.25 \mathrm{GPa}$. Hence only the melt was irradiated through the $100 \mu \mathrm{m}$ to $200 \mu \mathrm{m}$ window defined by the vertical space between the press anvils.

For the purpose of infrared and Mössbauer spectroscopic measurements, the samples were removed from the epoxy after electron microprobe analyses and double-polished down to $550 \mu \mathrm{m}$ (3.9 GPa run) and $300 \mu \mathrm{m}$ (6.25 GPa run). Infrared spectroscopic measurements were performed under vacuum using a Bruker IFS 66v/S Fourier transform infrared (FTIR) spectrometer, set with resistive Middle Infrared Globar SiC source with $3 \mathrm{~mm}$ optical aperture; a KBr beamsplitter and a $\mathrm{N}_{2}$-cooled MCT detector. Micro-focalisation was obtained by setting the sample in a homemade sample chamber at the focal point of two cassegrain reflectors. Transmission spectra were recorded in the range $550-9000 \mathrm{~cm}^{-1}$ with resolution of $4 \mathrm{~cm}^{-1}$ and accumulation of 64 scans. Analyzed spot is around $100 \mu \mathrm{m}$. Total water concentration (Table 1) was determined from the sum of structurally bonded hydroxyl groups and molecular water concentrations, using the Beer-Lambert law 
from the absorbances of the 4470 and $5210 \mathrm{~cm}^{-1}$ bands respectively, the baseline being fitted as a straight line (Fig.3 right). Molar absorption coefficients for $\mathrm{OH}$ and $\mathrm{H}_{2} \mathrm{O}$ bands were taken from Ohlhorst et al. (2001), and glass density taken from the present measurements (see below). Carbonate ions IR bands were saturating, thus requiring further polishing down of the sample. Instead, and to preserve the sample, $\mathrm{CO}_{3}^{2-}$ concentration was quantified by Raman spectroscopy using previously established calibration (Morizet et al., 2013). Raman spectra were collected in CSEC, University of Edinburgh, and at ISTO, University of Orléans. The Raman systems consisted of an argon laser (488 nm excitation in CSEC, $514 \mathrm{~nm}$ excitation at ISTO), a CCD detector and the spectra were collected using either a 1800 (CSEC) or 2400 (ISTO) grooves/mm grating, a laser power of $20 \mathrm{~mW}$, and a x50 objective. Although variations of the $\mathrm{CO}_{2}$ content are observed in the vicinity of the capsule walls, the bulk of the sample is characterized by a concentration of $0.9 \pm 0.1 \mathrm{wt} \%$ (middle curve, Fig. 3 left) and $2.1 \pm 0.5 \mathrm{wt} \%$ at respectively 3.9 $\mathrm{GPa}$ and $6.25 \mathrm{GPa}$. The uptake of reduced Fe by the Pt-Rh caps and concomitant oxidation of $\mathrm{C}$ from the capsule contributed to the formation of $\mathrm{CO}_{3}^{2-}$ units. For instance at $3.9 \mathrm{GPa}, 2.1 \mathrm{wt} \% \mathrm{FeO}$ (corresponding to 0.34 at $\% \mathrm{Fe}$, i.e. $17 \%$ of the total Fe content) was reduced to metallic Fe during the course of the experiments, thus potentially forming $0.65 \mathrm{wt} \% \mathrm{CO}_{3}^{2-}$ which is consistent with the estimates obtained from Raman spectroscopy. Our initial starting composition was carbonateand water-free. The volatile uptake by the melt occurred by equilibration at high P-T with the single-crystal diamond capsule for carbonate, and by diffusion from the epoxy gasket through the Pt-10\%Rh caps for water. Water contamination has 
been reported in previous experiments using the same cell-assembly (Perrillat et al., 2013).

Finally, the sample was analyzed by Mössbauer spectroscopy at the Bayerisches

GeoInstitut. The Mössbauer spectra were collected in transmission mode with a beam diameter of $500 \mu \mathrm{m}$ using a ${ }^{57} \mathrm{Co}$ in $\mathrm{Rh}$ point source. There is no evidence for the presence of $\mathrm{Fe}^{3+}$ species within the experimental uncertainty (estimated detection limit $\sim 2 \%$ ).

\subsection{Density of the melt from $x$-ray absorption scans}

X-ray absorption data were collected in situ using a monochromatic beam at 20 $\mathrm{keV}$. The observation of diffuse rings with the simultaneous disappearance of all crystalline diffraction peaks is used as the criterion to determine melting. Molten state of the sample was also systematically checked after the density measurement that takes $10 \mathrm{~min}$.

The absorption method consists of measuring the intensity of the X-ray beam with two ionization chambers before $\left(I_{0}\right)$ and after $(I)$ the crossing of the whole cell assembly. The absorption profile is recorded while moving the press perpendicular to the $\mathrm{x}$-ray beam axis. The intensity ratio obeys the Beer-Lambert law:

$$
\frac{I}{I_{o}}=\int_{x, y} \exp \left(-(\mu \rho d)_{l i q}-(\mu \rho d)_{e n v}\right) d x d y
$$

where $\mu$ is the mass absorption coefficient, $\rho$ the density, $d$ the X-ray path length, $x$ and $y$ respectively the horizontal and vertical size of the x-ray beam (50 $\mu \mathrm{m}$ width $\times 50 \mu \mathrm{m}$ height). The subscript $e n v$ stands for the environment surrounding the sample. Each absorption scan is simulated with relation (1) leading 
to values of $(\mu \rho)_{l i q}$ (Fig.4). Due to $\mathrm{CO}_{3}^{2-}$ and water dissolution in the melt, the value of $\mu_{l i q}$ could not be measured before melting from the density measured by $\mathrm{x}$-ray diffraction and the $\mu \rho$ product inferred from the absorption scans. Fe loss to the Pt-Rh caps is corrected for by assuming that only the mean molecular mass is affected, thus neglecting the effect on the volume. This results in a correction of $+0.9 \%$ at $3.9 \mathrm{GPa}$ and $+1.4 \%$ at $6.25 \mathrm{GPa}$. The ambient $\mathrm{P}$ density is obtained using the diffraction-based method (see below) on the sample recovered from $6.25 \mathrm{GPa}$, removed from the cell-assembly but still in its diamond capsule. This value, 2930 $\mathrm{kg} \cdot \mathrm{m}^{-3}$, was used to calculate $\mu$ from $(\mu \rho)_{0}\left(\mu=0.2916 \mathrm{~m}^{2} \cdot \mathrm{kg}^{-1}\right)$. We note that this density corresponds to a densified glass, as it was recovered from $6.25 \mathrm{GPa}$, consistently with the reported densification after decompression of samples melted at $6 \mathrm{GPa}$ (Kelsey et al., 2009).

\subsection{Structure and density of the melt from $x$-ray diffraction data}

The energy of the x-ray beam was switched to higher values, $46.8 \mathrm{keV}$, for x-ray diffraction measurements in order to increase the accessible 2- $\theta$ angle and consequently enlarge the reciprocal space. Diffraction data were recorded on a MAR350 image plate, with typical acquisition times of $2 \mathrm{~min}$. Contribution to the diffraction signal from parts surrounding the sample was filtered out by a multicollimator slit system (Morard et al., 2011).

The intensity data, $I(2 \theta)$, are converted into the structure factor, $S(q)$, using the Ashcroft-Langreth formalism (Ashcroft and Langreth, 1966). Note that in Fig.5, 


$$
\begin{gathered}
S(q)=\frac{\alpha I(q)}{Z^{2} f(q)^{2}} \\
\text { with } q=\frac{4 \pi}{\lambda} \sin (\theta), \quad Z=\sum_{i} x_{i} Z_{i} \quad \text { and } \quad f(q)=\frac{\sum_{i} x_{i} f_{i}(q)}{Z}
\end{gathered}
$$

where $\lambda$ is the $\mathrm{x}$-ray beam wavelength $(0.26472 \AA), x_{i}$ is the atomic fraction of the $i^{\text {th }}$ atom, $f_{i}(q)$ its form factor as tabulated by (Hajdu, 1972), $Z_{i}$ its atomic number and $\alpha$ is the Krogh-Moe and Norman normalization factor (Norman, 1957).

The radial distribution function, $g(r)$ is obtained from $S(q)$ :

$$
g(r)=1+\frac{1}{4 \pi r n} \int_{0}^{q_{\max }} q\left(S(q)-S_{\infty}\right) \sin (q r) d q
$$

where $q_{\max }$ is the maximum experimental q-range, $n=\frac{\rho \mathcal{N}_{A}}{M}, M$ the mean atomic molar mass (cf Table 2), and $\rho$ the density. Fe loss to the Pt-Rh caps is corrected for by using the mean atomic molar mass calculated with the starting $\mathrm{FeO}$ content. The method to derive density from x-ray diffraction data on melts was established for liquid mercury (Kaplow et al., 1965) and adapted to high pressure data (Eggert et al., 2002), and consists in minimizing the oscillations in $g(r)$ were there should not be any signal, i.e. below the minimum interatomic distance. We have applied this method here and the density found are in good agreement with those obtained from the x-ray absorption method (Table 2), albeit with a larger error bar at high $\mathrm{P}, \pm 0.002$ atoms $/ \AA^{3}$ on $n$ that translates into $\pm 2 \%$ on density.

The radial distribution functions obtained here are the sum of all ion-ion contributions. In order to evaluate the coordination number for $\mathrm{Si}-\mathrm{O}$ and $\mathrm{Al}-\mathrm{O}$ contri- 
butions (Table 2), we have simulated the experimental $g(r)$ against a sum of gaussians (where each gaussian corresponds to a particular ion-ion partial distribution function) with the following equation:

$$
g(r)=\frac{1}{n S_{\infty}} \sum_{i} \frac{A_{i}}{\sigma_{i} \sqrt{2 \pi}} \exp \left(-\frac{\left(r-d_{i}\right)^{2}}{2 \sigma_{i}^{2}}\right)
$$

where

$$
A_{i}=\frac{C N_{i}}{\int \frac{4 \pi r^{2}}{\sigma_{i} \sqrt{2 \pi}} \exp \left(\frac{-\left(r-d_{i}\right)^{2}}{2 \sigma_{i}^{2}}\right) d r}
$$

where $C N_{i}$ is the coordination number of the $i^{t h}$ ion-ion contribution, $d_{i}$ the corresponding inter-atomic distance, and $\sigma_{i}$ a parameter depending on structural disorder (Hosemann and Bagchi, 1962), $\sigma_{i}=k \sqrt{d_{i}} . k$ is an adjustable parameter (typically $0.15-0.17$ ). We want to determine the coordination number of the two first contributions, $\mathrm{Si}-\mathrm{O}$ and $\mathrm{Al}-\mathrm{O}$, that make most of the first peak in $g(r)$ at $1.6 \AA$. For this purpose, only ion-ion contributions with $d_{i}$ up to $3 \AA$ need to be considered as further contributions does not contribute to the first peak. Those contributions are $\mathrm{Si}-\mathrm{O}, \mathrm{Al}-\mathrm{O}, \mathrm{Mg}-\mathrm{O}, \mathrm{Fe}-\mathrm{O}, \mathrm{Ca}-\mathrm{O}, \mathrm{O}-\mathrm{O}$ and $(\mathrm{Si}-\mathrm{O})_{2}$. Note that the contribution of $\mathrm{Mg}-\mathrm{O}$ is almost identical to that calculated at ambient pressure for molten $\mathrm{An}_{0.36^{-}}$ $\mathrm{Di}_{0.64}$ with a similar $\mathrm{MgO}$ content (Vuilleumier et al., 2009).

\section{Results}

Density measurements using both methods, absorption and diffraction, were done successively at high P-T conditions and are summarized on Fig.6. Data were collected at $3.9 \mathrm{GPa}-1850 \mathrm{~K}$ and $6.25 \mathrm{GPa}-1910 \mathrm{~K}$ (Fig.1), i.e. at subliquidus 
conditions as confirmed by the presence of crystals in the quench samples (Fig.2).

Data were then reduced to the $1673 \mathrm{~K}$ isotherm relevant for the LAB using 7.4 $10^{-5} \mathrm{~K}^{-1}$ for the thermal expansion coefficient, value calculated at $5 \mathrm{GPa}$ (Guillot and Sator, 2007a). The obtained density are in the lower range of previous shock-wave data (Rowan, 1993) but above the shock-wave equation of state measured for molten $\mathrm{An}_{0.36}-\mathrm{Di}_{0.64}$ and applied to basaltic composition (Rigden et al., 1984), and 2.3\% higher than the sink-float data point on dry MORB (Agee, 1998). A recurrent difficulty for volatile-containing magmas is to determine their ambient pressure density, due to the fact that the dissolved volatile content is strongly pressure dependent. As discussed by Agee (2008), recent studies on the density of hydrous silicate melts (Sakamaki et al., 2006, 2009) have anchored their high pressure data to the ambient density value calculated using the partial molar volume of $\mathrm{H}_{2} \mathrm{O}$ and its temperature derivative derived at $1000^{\circ} \mathrm{C}$ from 1-bar density measurements on hydrous $\mathrm{SiO}_{2}$-rich and Fe-free silicate glasses synthesized at $1 \mathrm{GPa}$ (Ochs III and Lange, 1999). It is unclear if such values can be extrapolated to more mafic compositions and higher temperatures; we instead calculated the partial volume of $\mathrm{H}_{2} \mathrm{O}$ from the lowest $\mathrm{P}$ density measurements on mafic melts (Agee, 2008) at $1.4 \mathrm{GPa}-1773 \mathrm{~K}$ (i.e. $11.24 \mathrm{cc} / \mathrm{mol}$ ), a temperature reasonably close to $1673 \mathrm{~K}$, and applied it to the density of dry molten basalt (Rigden et al., 1984). This value at 1.4 GPa and our high pressure data points obtained from both $\mathrm{x}$-ray absorption and x-ray diffraction methods were fitted with a third order Birch-Murnaghan equation of state, with $\mathrm{K}_{0,1673 K}=18.1 \pm 1.2 \mathrm{GPa}$ assuming $\mathrm{K}_{0,1673 K}^{\prime}=5$ for the sake of comparison with previous data. These values, when compared to those obtained 
for a MORB+2 wt $\% \mathrm{H}_{2} \mathrm{O}$ at higher P-T conditions (14-20 GPa and $2573 \mathrm{~K}$ ), i.e. $\mathrm{K}_{0,2573 K}=13.8 \pm 2.2 \mathrm{GPa}$ assuming $\mathrm{K}_{0,2573 K}^{\prime}=5$ (Sakamaki et al., 2006), imply $\partial K / \partial T=4.810^{-3} \mathrm{GPa} \cdot \mathrm{K}^{-1}$. The $\mathrm{H}_{2} \mathrm{O}$ component is very compressible in silicate melts (Ochs III and Lange, 1999; Sakamaki et al., 2006; Agee, 2008). Consequently, its effect on the density is very strong at low $\mathrm{P}$ but decreases a lot under increased compression, rapidly leveling off above a few GPa.

The expected effect of dissolved water and carbonate ions in basalts is an increase of ${ }^{\mathrm{V}} \mathrm{Al}$ and ${ }^{\mathrm{VI}} \mathrm{Al}$ at the expense of ${ }^{\mathrm{IV}} \mathrm{Al}$, as suggested from NMR studies on quenched glasses for water (Malfait et al., 2011; Xue and Kanzaki, 2008), and by molecular dynamic calculations (Guillot and Sator, 2011) and infra-red spectroscopy (Taylor, 1990) for carbonate ions. As our experiments were conducted not only in situ at high P-T but also at pressures higher than those of the NMR and IR studies (0.2 GPa for Xue and Kanzaki (2008) and up to 3.5 GPa for Malfait et al. (2011)), we might expect this effect to be more pronounced as Al of higher coordinations are favoured by high pressure (Allwardt et al., 2007). Indeed, increased Al-O coordination number is observed in our structural data (Fig.5 and Table 2), reaching 5.3 at 6.25 GPa while MD calculations predict 4.6 only for a dry MORB at $5 \mathrm{GPa}$ (Guillot and Sator, 2007b). In contrast, our observed Si-O coordination number, 4.15 at $6.25 \mathrm{GPa}$, is similar to the MD calculated value of 4.1 at $5 \mathrm{GPa}$. Both carbonate and water components might increase the network polymerization of basaltic melts (Xue and Kanzaki, 2008). The Si-O-Si vibrational modes are observed at low frequencies in the quenched glass (Fig.4), in the $450-550 \mathrm{~cm}^{-1}$ region, although the quenched glass might not be an appropriate proxy for the high 
$\mathrm{P}$ melt. The frequency of these modes normally ranges from 400 to $700 \mathrm{~cm}^{-1}$ depending on glass composition, and has been related to the degree of polymerization, the lower the frequency the more polymerized the glass (McMillan, 1984). The increased polymerization is also reflected in the $\mathrm{x}$-ray diffraction data as the the first sharp diffraction peak gets more intense while shifting to slightly lower $q$-values between the starting and quenched glasses (Fig.5 left). These increased Al-O coordination number and melt polymerization might therefore compensate for the slight mass deficit induced by the presence of volatiles, hence providing an explanation for the matched density with dry MORB at high pressures.

\section{Discussion: nature of the continental lithosphere-asthenosphere boundary}

To assess the buoyancy of volatile-containing alkali basalts, our density data are compared to petrological density profiles (Poudjom Djomani et al., 2001; James et al., 2004), and to the radially averaged PREM mantle density profile (Dziewonski and Anderson, 1981) (Fig.6). Regional seismically-derived density profiles exist westwards of the North American craton (Ito and Simons, 2011) but not for intracratonic contexts. Nonetheless, petrological density data on xenoliths (James et al., 2004) do overlap with PREM values for the deep lithosphere. Compared to PREM and concordant petrological data, the alkali basalt is just neutrally buoyant at the LAB, trapped between the depleted lithosphere and the fertile and denser asthenosphere. It is also clear from this comparison that such melts will not be neutrally buoyant at the conditions of the oceanic LAB (Fig.6). The PREM model 
probes the current-day Earth, the petrological profiles established from xenoliths are relevant for the last Gy or so. Because the melt is just neutrally buoyant at the continental $\mathrm{LAB}$, that means that for pre-proterozoic ages when the mantle was hotter, they likely were positively buoyant. Indeed, the thermal expansion coefficient of lithospheric and sub-lithospheric mantle is approximately $310^{-5} \mathrm{~K}^{-1}$ (cf Korenaga (2007) and refs. therein), i.e. 2.5 times less that of the basaltic melt (Guillot and Sator, 2007a). Using that value for the mantle thermal expansion and the asthenospheric PREM density value, we calculate that alkali basalts will cease to be neutrally buoyant for temperatures hotter by $270 \mathrm{~K}$ than present-day ones. Such high temperatures existed during the Archean about 3 Ga ago (Herzberg et al., 2010), time at which different geochemical indicators point to the initiation of plate tectonics (Shirey and Richardson, 2011; Dhuime et al., 2012). Essential to the establishment of plate tectonics is their lubrication. Although water has long been held responsible for viscosity softening in the asthenosphere, latest experimental work showed that water has in fact very little effect (Fei et al., 2013), and neither has a tiny melt fraction ( $1 \%$ level). Thin pockets or a layer of molten basalt could thus provide a better explanation for lithosphere/asthenosphere decoupling below continents from mid-Archean on. As such, they could have plaid a major role in the initiation of plate tectonics.

This is yet another example of density trap playing a key role in planetary evolution. Partial melts layers or pockets have been evidenced at the bottom of the Earth's and lunar mantles (Williams and Garnero, 1996; Weber et al., 2011; Van Kan Parker et al., 2012), where they likely trap incompatible heat producing 
elements and as such blanket the core. A partial melt layer has been reported at the terrestrial 410-km discontinuity from seismology (Tauzin et al., 2010) and electrical resistivity measurements (Toffelmier and Tyburczy, 2007), i.e. in the present-day Earth, and its existence has also been postulated in the early Archean

(Lee et al., 2010). These dense liquids would constitute hidden enriched reservoirs at depth. The occurrences of stable layers of magmas at depth could therefore prove more widespread than previously thought both in time and space, and must have exerted a strong control on the structure, geochemistry and dynamics of planetary silicate mantles.

\section{Acknowledgements.}

This work was funded by an ERC Starting Grant (FP7 grant agreement no. 259649

to C. S.), the french Programme National de Planétologie and ISTeP through its internal funding system. We acknowledge the ESRF for provision of beamtime on ID27, Catherine McCammon for Mössbauer spectroscopy measurements at the Bayerisches GeoInstitut, Chris Hayward for his help with electron microprobe analyses, Angel Arévalo-López for help with the ex situ synthesis, and Keevin Béneut and Marc Blanchard for IR analyses. 


\section{Figure captions.}

Figure 1. Experimental P-T conditions compared to melting relationships for alkali basalt (Tsuruta and Takahashi, 1998), mid-oceanic ridge basalts (MORB) (Yasuda et al., 1994), GA2 eclogite (Spandler et al., 2004), and geotherm estimates covered by the orange shading (James et al., 2004). The effect of added $\mathrm{K}_{2} \mathrm{O}(+1.5 \mathrm{wt} \%)$, $\mathrm{CO}_{2}$ and $\mathrm{H}_{2} \mathrm{O}$ on the solidus of the $\mathrm{GA} 2$ eclogite is shown $(-250 \mathrm{~K})$. N.B.: alkali basalt and MORB have a very similar liquidus curve.

Figure 2. Scanning electron microscope image of the sample quenched from 3.9 GPa-1850 K, and annotated sketch; the grey square represent the x-ray window.

Figure 3. Left: Raman spectra taken on the quenched samples (black lines: 3.9 GPa, grey line: $6.25 \mathrm{GPa}$ ); bottom curve: spectrum representative of the bulk of the sample, top and middle curves: spectra taken close to the capsule walls. Right: IR spectra (black line: $3.9 \mathrm{GPa}$, grey line: $6.25 \mathrm{GPa}$ ); note that the samples have different thicknesses (550 $\mu \mathrm{m}$ for the $3.9 \mathrm{GPa}$ run, $300 \mu \mathrm{m}$ for the $6.25 \mathrm{GPa}$ run).

Figure 4. X-ray absorption scans collected in situ on the melt at $6.25 \mathrm{GPa}-1850 \mathrm{~K}$ (top) and ex situ on the quenched sample still in its diamond capsule but removed from the cell-assembly (bottom). Red curves: data, black dashed curves: fit with the Beer-Lambert law. The strong absorption signal on the left-hand side of the 
sample is due to the platinum foil inserted for P-T calibration purposes.

Figure 5. Structure of the starting glass, high pressure melts and quenched glass. Left: structure factor, $S(q)$. Right: radial distribution function, $g(r)$, of the melt at 6.25 GPa-1910 K (solid black curve) and fit to the data with ion-ion contributions up to $3 \AA$ Ar. Are represented only the main ion-ion contributions significant before $1.8 \AA$, i.e. below the first peak in $g(r)$.

Figure 6. Density of melt as a function of pressure at $1673 \mathrm{~K}$ (black full squares: density from x-ray absorption, black full diamonds: density from x-ray diffraction, full circle: calculation at $1.4 \mathrm{GPa}$ for $1.04 \mathrm{wt} \%$ dissolved $\mathrm{H}_{2} \mathrm{O}$ in MORB), compared to seismological models (green solid line: PREM model (Dziewonski and Anderson, 1981), blue line: Pacific profile (Ito and Simons, 2011)), density model for cratons (green dashed line (Poudjom Djomani et al., 2001)), and petrological values of the density for surrounding rocks (full green circles: harzburgite xenoliths, empty green circles: lherzolite xenoliths (James et al., 2004)). Black solid line: third order Birch-Murnaghan equation of state through our density data +1.4 GPa estimate; the grey zone illustrates the effect on this equation of state of $\mathrm{T}$ variations of $\pm 100 \mathrm{~K}$, reflecting the range of $\mathrm{T}$ reported for the continental $\mathrm{LAB}$; open diamonds: shock-wave data on molten MORB (Rowan, 1993), black dashed line: shock-wave equation of state measured on Anorthite ${ }_{36}$-Diopside 64 melt and applied to a MORB composition (Rigden et al., 1984), empty square: sink-float 
429 data on molten MORB (Agee, 1998). 


\begin{tabular}{|c|c|c|c|}
\hline \multirow[t]{2}{*}{ Oxide } & \multirow{2}{*}{$\begin{array}{c}\text { Starting } \\
\text { composition } \\
\text { (Pichavant et al., 2009) }\end{array}$} & \multicolumn{2}{|c|}{ Quenched glass } \\
\hline & & $3.90 \mathrm{GPa}$ & $6.25 \mathrm{GPa}$ \\
\hline $\mathrm{SiO}_{2}$ & $50.2(3)$ & $50.1(2)$ & $50.9(5)$ \\
\hline $\mathrm{TiO}_{2}$ & $0.84(4)$ & $0.82(2)$ & $0.66(2)$ \\
\hline $\mathrm{Al}_{2} \mathrm{O}_{3}$ & $15.2(3)$ & $15.6(1)$ & $15.4(6)$ \\
\hline $\mathrm{FeO}$ & $7.81(12)$ & $5.68(9)$ & 4.41(30) \\
\hline $\mathrm{MnO}$ & $0.16(5)$ & $0.15(8)$ & $0.10(2)$ \\
\hline $\mathrm{MgO}$ & $7.87(12)$ & $6.97(3)$ & $6.65(15)$ \\
\hline $\mathrm{CaO}$ & $12.4(2)$ & $11.0(3)$ & $11.88(16)$ \\
\hline $\mathrm{Na}_{2} \mathrm{O}$ & $2.29(5)$ & $2.46(1)$ & $2.47(3)$ \\
\hline $\mathrm{K}_{2} \mathrm{O}$ & $1.86(6)$ & $1.99(4)$ & $1.91(2)$ \\
\hline $\mathrm{P}_{2} \mathrm{O}_{5}$ & $0.64(6)$ & $0.49(2)$ & $0.47(2)$ \\
\hline $\mathrm{Cr}_{2} \mathrm{O}_{3}$ & $0.05(5)$ & not det. & not det. \\
\hline $\mathrm{NiO}$ & $0.03(3)$ & not det. & not det. \\
\hline $\mathrm{CO}_{3}^{2-*}$ & - & $0.9(1)$ & $2.1(5)$ \\
\hline $\mathrm{H}_{2} \mathrm{O}^{* *}$ & - & $1.04(4)$ & $1.4(2)$ \\
\hline Total & 99.1 & 97.24 & 98.35 \\
\hline
\end{tabular}

Table 1: Composition of the starting material and of the recovered glass samples. Data given in wt\%, one standard deviation given in parentheses in terms of last digit. ${ }^{*}$ Carbonate ions concentration is derived from Raman spectra. ${ }^{* *}$ Water content is derived from infra-red spectra. 


\begin{tabular}{|c|c|c|c|c|c|c|c|c|}
\hline Technique & \multicolumn{3}{|c|}{ X-ray absorption } & \multicolumn{5}{|c|}{$\mathrm{X}$-ray diffraction } \\
\hline P-T conditions & $\begin{array}{c}\text { run duration } \\
\text { at } \mathrm{T}\end{array}$ & $\begin{array}{l}\rho \mu \text { at } \mathrm{T} \\
\left(\AA^{-1}\right)\end{array}$ & $\begin{array}{c}\rho \text { at } 1673 \mathrm{~K} \\
\left(\mathrm{~kg} \cdot \mathrm{m}^{-3}\right)\end{array}$ & $\begin{array}{c}\rho \text { at } \mathrm{T} \\
\left(\text { atoms } \cdot \AA^{-3}\right)\end{array}$ & $\begin{array}{c}M \\
\mathrm{~g} / \mathrm{mole}\end{array}$ & $\begin{array}{c}\rho \text { at } 1673 \mathrm{~K} \\
\left(\mathrm{~kg} \cdot \mathrm{m}^{-3}\right)\end{array}$ & $\begin{array}{l}\mathrm{Si}-\mathrm{O} \\
\mathrm{CN}\end{array}$ & $\begin{array}{l}\mathrm{Al}-\mathrm{O} \\
\mathrm{CN}\end{array}$ \\
\hline & & & & & & & & \\
\hline $3.90 \mathrm{GPa}-1850 \mathrm{~K}$ & $33 \mathrm{~min}$ & 900 & $3154 \pm 30$ & $0.088 \pm 0.0020$ & 21.126 & $3128 \pm 70$ & 4.10 & 4.3 \\
\hline $6.25 \mathrm{GPa}-1910 \mathrm{~K}$ & $43 \mathrm{~min}$ & $950 \pm 5$ & $3361 \pm 31$ & $0.0925 \pm 0.0020$ & 21.015 & $3315 \pm 70$ & 4.15 & 5.3 \\
\hline quenched sample & - & 850 & - & $0.0835 \pm 0.0005^{*}$ & 21.015 & $2930 \pm 20^{*}$ & 4.05 & 4.4 \\
\hline
\end{tabular}

Table 2: Summary of absorption and diffraction data. CN stands for coordination number.*: for the quenched sample density values are given at room $\mathrm{T}$. 


\section{References}

Agee, C.B., 1998. Crystal-liquid density inversions in terrestrial and lunar magmas. Phys. Earth Planet. Int. 107, 63-74.

Agee, C.B., 2008. Static compression of hydrous silicate melt and the effect of water on planetary differentiation. Earth Planet. Sci. Lett. 265, 641-654.

Allwardt, J.R., Stebbins, J.F., Hidenori, T., Du, L.S., Frost, D.J., Withers, A.C., Hirschmann, M.M., Suzuki, A., Ohtani, E., 2007. Effect of structural transitions on properties of high-pressure silicate melts: Al-27 NMR, glass densities, and melt viscosities. Am. Miner. 92, 1093-1104.

Anderson, D.L., Sammis, C., 1970. Partial melting in the upper mantle. Phys. Earth Planet. Int. 3, 41-50.

Ashcroft, N.W., Langreth, D., 1966. Structure of binary liquid mixtures. I. Phys. Rev. 156, 685-692.

Butvina, V.G., Safonov, O.G., Litvin, Y.A., 2009. Experimental study of eclogite melting with participation of the $\mathrm{H}_{2} \mathrm{O}-\mathrm{CO}_{2}-\mathrm{KCl}$ fluid at $5 \mathrm{GPa}$. Doklady Earth Sci. 427, 956-960.

Cammarano, F., Romanowicz, B., 2007. Insights into the nature of the transition zone from physically constrained inversion of long-period seismic data. Proc. Nat. Acad. Sci. 104, 9139-9144. 
Carlson, R.W., Pearson, D.G., James, D.E., 2005. Physical, chemical, and chronological characteristics of continental mantle. Rev. Geophy. 43, RG1001.

Chen, G.Q., Ahrens, T.J., Stolper, E.M., 2002. Shock-wave equation of state of molten and solid fayalite. Phys. Earth Planet. Int. 134, 35-52.

Dasgupta, R., Mallik, A., Tsuno, K., Withers, A.C., Hirth, G., Hirschmann, M.M., 2013. Carbon-dioxide-rich silicate melt in the Earth's upper mantle. Nature 493, $211-216$.

Dhuime, B., Hawkesworth, C., Cawood, P., Storey, C., 2012. A change in the geodynamics of continental growth 3 billion years ago. Science 335, 13341336. doi:10.1126/science. 1216066 .

Doglioni, C., Ismail-Zadeh, A., Panza, G., Riguzzi, F., 2011. Lithosphereasthenosphere viscosity contrast and decoupling. Phys. Earth Planet. Int. 189, $1-8$.

Dziewonski, A.M., Anderson, D.L., 1981. Preliminary reference Earth model. Phys. Earth Planet. Int. 25, 297-356.

Eaton, D.W., Darbyshire, F., Evans, R.L., Grutter, H., Jones, A.G., Yuan, X., 2009. The elusive lithosphere-asthenosphere boundary (LAB) beneath cratons. Lithos $109,1-22$

Eggert, J.H., Weck, G., Loubeyre, P., Mezouar, M., 2002. Quantitative structure factor and density measurements of high-pressure in diamond anvil cells by $\mathrm{x}$ ray diffraction: Argon and water. Phys. Rev. B 65, 174105-1-174105-12. 
Fei, H., Wiedenbeck, M., Yamazaki, D., Katsura, T., 2013. Small effect of water on upper-mantle rheology based on silicon self-diffusion coefficients. Nature 498, 213-216. doi:10.1038/nature12193.

Foley, S.F., 2008. Rejuvenation and erosion of the cratonic lithosphere. Nature Geosci. 1, 503-510. doi:10.1038/ngeo261.

Foley, S.F., Yaxley, G.M., Rosenthal, A., Buhre, S., Kiseeva, E.S., Rapp, R.P., Jacob, D.E., 2009. The composition of near-solidus melts of peridotite in the presence of $\mathrm{CO}_{2}$ and $\mathrm{H}_{2} \mathrm{O}$ between 40 and 60 kbar. Lithos 112, 274-283.

Gaillard, F., Malki, M., Iacono-Marziano, G., Pichavant, M., Scaillet, B., 2008. Carbonatite melts and electrical conductivity in the asthenosphere. Science 322, $1363-1365$

Gerbode, C., Dasgupta, R., 2010. Carbonate-fluxed melting of MORB-like pyroxenite at 2.9 GPa and genesis of HIMU ocean island basalts. J. Pet. 51, 20672088.

Guillot, B., Sator, N., 2007a. A computer simulation study of natural silicate melts. Part I: low pressure properties. Geochim. Cosmochim. Acta 71, 1249-1265.

Guillot, B., Sator, N., 2007b. A computer simulation study of natural silicate melts. Part II: High pressure properties. Geochim. Cosmochim. Acta 71, 4538-4556.

Guillot, B., Sator, N., 2011. Carbon dioxide in silicate melts: A molecular dynamics simulation study. Geochim. Cosmochim. Acta 75, 1829-1857. 
Hajdu, F., 1972. Revised parameters of the analytic fits for coherent and incoherent scattered x-ray intensities of the first 36 atoms. Acta Cryst. , 250-252.

Harte, B., 2010. Diamond formation in the deep mantle: the record of mineral inclusions and their distribution in relation to mantle dehydration zones. Min. Mag. 74, 189-215.

Herzberg, C., Condie, K., Korenaga, J., 2010. Thermal history of the Earth and its petrological expression. Earth Planet. Sci. Lett. 292, 79-88.

Hirano, N., Takahashi, E., Yamamoto, J., Abe, N., Ingle, S.P., Kaneoka, I., Hirata, T., Kimura, J.I., Ishii, T., Ogawa, Y., Machida, S., Suyehiro, K., 2006. Volcanism in response to plate flexure. Science 313, 1426-1428.

Hofmann, A.M., 2003. Sampling mantle heterogeneity through oceanic basalts: isotopes and trace elements, in: R. Carlson (Ed.), Treatise on geochemistry. The mantle and core, Elsevier, Amsterdam. pp. 61-97.

Hosemann, R., Bagchi, S.N., 1962. Direct Analysis of Diffraction by Matter. North-Holland, Amsterdam.

Ito, T., Simons, M., 2011. Probing asthenospheric density, temperature, and elastic moduli below the western United States. Science 332, 947-951.

James, D.E., Boyd, F.R., Schutt, D., Bell, D.R., Carlson, R.W., 2004. Xenolith constraints on seismic velocities in the upper mantle beneath southern Africa. $\mathrm{G}^{3}$ 5, Q01002. 
Jones, A.G., 1999. Imaging the continental upper mantle using electromagnetic methods. Lithos 48, 57-80.

Jones, A.G., Plomerov, J., Korja, T., Sodoudi, F., Spakman, W., 2010. Europe from the bottom up: A statistical examination of the central and northern European lithosphere-asthenosphere boundary from comparing seismological and electromagnetic observations. Lithos 120, 14-29.

Kaplow, R., Strong, S.L., Averbach, B.L., 1965. Radial density functions for liquid mercury and lead. Phys. Rev. 138, A1336.

Kelemen, P.B., Hart, S.R., Bernstein, S., 1998. Silica enrichment in the continental upper mantle via melt/rock reaction. Earth Planet. Sci. Lett. 164, 387-406.

Kelsey, K.E., Stebbins, J.F., Mosenfelder, J.L., Asimow, P.D., 2009. Simultaneous aluminum, silicon, and sodium coordination changes in $6 \mathrm{GPa}$ sodium aluminosilicate glasses. Am. Min. 94, 1205-1215.

King, S.D., 2005. Archean cratons and mantle dynamics. Earth Planet. Sci. Lett. $234,1-14$

Kiseeva, E.S., Yaxley, M.Y., Hermann, J., Litasov, K.D., Rosenthal, A., Kamenetsky, V.S., 2012. An experimental study of carbonated eclogite at 3.5-5.5 GPaImplications for silicate and carbonate metasomatism in the cratonic mantle. J. Petrol. 53, 727-759. doi:10.1093/petrology/egr078.

Kogiso, T., Hirschmann, M.M., Reiners, P.W., 2004. Length scales of man- 
tle heterogeneities and their relationship to ocean island basalt geochemistry. Geochim. Cosmochim. Acta 68, 345-360.

Korenaga, J., 2007. Effective thermal expansivity of Maxwellian oceanic lithosphere. Earth Planet. Sci. Lett. 257, 343-349.

Lee, C.T.A., 2006. Geochemical/petrologic constraints on the origin of cratonic mantle, in: Benn, K and Mareschal, J. C and Condie, K. C (Ed.), Archean geodynamics and environments, pp. 89-114. doi:10.1029/164GM08.

Lee, C.T.A., Luffi, P., Höink, T., Li, J., Dasgupta, R., Hernlund, J., 2010. Upsidedown differentiation and generation of a primordial lower mantle. Nature 463, 930-935.

Malfait, W.J., Verel, R., Ardia, P., Sanchez-Valle, C., 2011. Aluminum coordination in rhyolite and andesite glasses and melts: Effect of temperature, pressure, composition and water content. Geochim. Cosmochim. Acta 77, 11-26.

Malik, A., Dasgupta, R., 2013. Reactive infiltration of MORB-eclogite-derived carbonated silicate melt into fertile peridotite at $3 \mathrm{GPa}$ and genesis of alkalic magmas. J. Petrol. 54, 2267-2300.

McMillan, P.F., 1984. Structural studies of silicate glasses and melts-applications and limitations of Raman spectroscopy. Am. Mineral. 69, 622-644.

Mikhail, S., Dobosi, G., Verchovsky, A.B., Kurat, G., Jones, A.P., 2013. Peridotitic and websteritic diamondites provide new information regarding mantle 
melting and metasomatism induced through the subduction of crustal volatiles. Geochim. Cosmochim. Acta 107, 1-11.

Morard, G., Mezouar, M., Bauchau, S., M.lvarez-Murga, Hodeau, J.L., Garbarino, G., 2011. High efficiency multichannel collimator for structural studies of liquids and low-Z materials at high pressures and temperatures. Rev. Sci. Instrum. $82,023904$.

Morizet, Y., Brooker, R.A., Iacono-Marziano, G., Kjarsgaard, B.A., 2013. Quantification of $\mathrm{CO}_{2}$ dissolved in silicate glasses of various compositions with micro-Raman spectroscopy. Am. Mineral. 98, 1788-1802.

Norman, N., 1957. The Fourier transform method for normalizing intensities. Acta Cryst. 10, 370-373.

Ochs III, F.A., Lange, R.A., 1999. The density of hydrous magmatic liquids. Science $283,1314-1317$.

Ohlhorst, S., Behrens, H., Holtz, F., 2001. Compositional dependence of molar absorptivities of near-infrared $\mathrm{OH}-$ and $\mathrm{H}_{2} \mathrm{O}$ bands in rhyolitic to basaltic glasses. Chem. Geol. 174, 5-20.

O'Reilly, S.Y., Griffin, W.L., 2010. The continental lithosphere-asthenosphere boundary: Can we sample it? Lithos 120, 1-13.

Perrillat, J.P., Daniel, I., Bolfan-Casanova, N., Chollet, M., Morard, G., Mezouar, M., 2013. Mechanism and kinetics of the $\alpha-\beta$ transition in San Carlos olivine $\mathrm{Mg}_{1.8} \mathrm{Fe}_{0.2} \mathrm{SiO}_{4}$. J. Geophys. Res. 118, 1-10. 
Pertermann, M., Hirschmann, M.M., 2003. Partial melting experiments on a MORB-like pyroxenite between 2 and $3 \mathrm{GPa}$ : Constraints on the presence of pyroxenite in basalt source regions from solidus location and melting rate. J. Geophys. Res. 108, 2125.

Pichavant, M., di Carlo, I., Gac, Y.L., Rotolo, S.G., Scaillet, B., 2009. Experimental constraints on the deep magma feeding system at Stromboli volcano, Italy. J.Pet. 50, 601-624.

Poudjom Djomani, Y.H., O’Reilly, S.Y., Griffin, W.L., Morgan, P., 2001. The density structure of subcontinental lithosphere through time. Earth Planet. Sci. Lett. 184, 605-621.

Rigden, S.M., Ahrens, T.J., Stolper, E.M., 1984. Densities of liquid silicate at high pressures. Science 226, 1071-1074.

Rohrbach, A., Ballhaus, C., Golla-Schindler, U., Ulmer, P., Kamenetsky, V.S., Kuzmin, D.V., 2007. Metal saturation in the upper mantle. Nature 449, 456-458. doi:10.1038/nature06183.

Rohrbach, A., Ballhaus, C., Ulmer, P., Golla-Schindler, U., Schoenbohm, D., 2011. Experimental evidence for a reduced metal-saturated upper mantle. J. Pet. 449, 456-458. doi:10.1093/petrology/egq101.

Rowan, L., 1993. I. Equation of state of molten mid-ocean ridge basalt. II. Structure of Kilauea volcano. Ph.D. thesis. California Institute of Technology. 
Rudnick, R.L., McDonough, W.F., Orpin, A., 1994. Northern Tanzanian peridotite xenoliths: a comparison with Kaapvaal peridotites and inferences on metasomatic interactions, in: H. O. A. Meye and O. Leonardos (Ed.), Kimberlites, related rocks, and mantle xenoliths, pp. 336-353.

Sakamaki, T., Ohtani, E., Urakawa, S., Suzuki, A., Katayama, Y., 2009. Measurement of hydrous peridotite magma density at high pressure using the x-ray absorption method. Earth Planet. Sci. Lett. 287, 293-297.

Sakamaki, T., Suzuki, A., Ohtani, E., 2006. Stability of hydrous melt at the base of the Earth's upper mantle. Nature 439, 192-194.

Schultze, D.J., 1989. Constraints on the abundance of eclogite in the upper mantle. J. Geophys. Res. 94, 4205-4212.

Shirey, S.B., Richardson, S.H., 2011. Start of the Wilson cycle at $3 \mathrm{Ga}$ shown by diamonds from subcontinental mantle. Science 333, 434-436. doi:10.1126/science.1206275.

Sobolev, A.V., Hofmann, A.W., Kusmin, D.V., Yaxley, G.M., Arndt, N.T., Chung, S.L., Danyushevsky, L.V., Elliott, T., Frey, F.A., Garcia, M.O., Gurenko, A.A., Kamenetsky, V.S., Kerr, A.C., Krivolutskaya, N.A., Matvienkov, V.V., Nikogosian, I.K., Rocholl, A., Digurdsson, I.A., Sushchevskaya, N.M., Teklay, M., 2007. The amount of recycled crust in sources of mantle-derived melts. Science $316,412-417$. 
Sobolev, A.V., Hofmann, A.W., Sobolev, S.V., Nikogosian, K., 2005. An olivinefree mantle source of Hawaiian shield basalts. Nature 434, 590-597.

Spandler, C., Hermann, J., Arculus, R.J., Mavrogenes, J.A., 2004. Geochemical heterogeneity and element mobility in deeply subducted oceanic crust; insights from high-pressure mafic rocks from New Caledonia. Chem. Geol. 206, 21-42.

Spandler, C., Yaxley, G., Green, D.H., Rosenthal, A., 2008. Phase relations and melting of anhydrous K-bearing eclogite from 1200 to $1600^{\circ} \mathrm{C}$ and 3 to $5 \mathrm{GPa}$. J. Pet. 49, 771-795.

Tauzin, B., Debayle, E., Wittlinger, G., 2010. Seismic evidence for a global lowvelocity layer within the Earths upper mantle. Nature Geoscience 3, 718-721.

Taylor, W.R., 1990. The dissolution mechanism of $\mathrm{CO}_{2}$ in aluminosilicate melts - infrared spectroscopic constraints on the cationic environment of dissolved $\left[\mathrm{CO}_{3}\right]^{2-}$. Eur. J. Mineral. 2, 547-563.

Toffelmier, D.A., Tyburczy, J.A., 2007. Electromagnetic detection of a 410km-deep melt layer in the southwestern United States. Nature 447, 991-994. doi:10.1038/nature05922.

Tsuruta, K., Takahashi, E., 1998. Melting study of an alkali basalt JB-1 up to 12.5 GPa: behavior of potassium in the deep mantle. Phys. Earth Planet. Int. 107, 119-130.

Van Kan Parker, M., Sanloup, C., Sator, N., Guillot, B., Tronche, E.J., Perrillat, J.P., Mezouar, M., Rai, N., van Westrenen, W., 2012. Neutral buoyancy of 
titanium-rich melts in the deep lunar interior. Nature Geoscience 5, 186-189. doi:10.1038/NGEO1402.

Van Kan Parker, M., Sanloup, C., Tronche, E.J., Perrillat, J.P., Mezouar, M., Rai, N., van Westrenen, W., 2010. Calibration of a diamond capsule cell assembly for in situ determination of liquid properties in the Paris-Edinburgh press. High Pressure Res. 30, 332-341.

Vuilleumier, R., Sator, N., Guillot, B., 2009. Computer modeling of natural silicate melts: What can we learn from ab initio simulations. Geochim. Cosmchim. Acta 73, 6313-6339.

Weber, R.C., Lin, P.Y., Garnero, E.J., Williams, Q., Lognonné, P., 2011. Seismic detection of the lunar core. Science 331, 309-312.

Williams, Q., Garnero, E.J., 1996. Seismic evidence for partial melt at the base of Earth's mantle. Science 273, 1528-1530.

Xue, X., Kanzaki, M., 2008. Structure of hydrous aluminosilicate glasses along the diopside-anorthite join: A comprehensive one- and two-dimensional ${ }^{1} \mathrm{H}$ and ${ }^{27}$ Al NMR study. Geochim. Cosmochim. Acta 72, 2331-2348.

Yasuda, A., Fuji, T., Kurita, K., 1994. Melting phase relations of an anhydrous midocean ridge basalt from 3 to $20 \mathrm{GPa}$ : Implications for the behavior of subducted oceanic crust in the mantle. J. Geophys. Res. 99, 9401-9414.

Yaxley, G.M., Green, D.H., 1998. Reactions between eclogite and peridotite: man- 
652 tle refertilisation by subduction of oceanic crust. Schweiz. Mineral. Petrogr. Mitt. 78, 243-255.

654 Yoshino, T., Yamazaki, D., Mibe, K., 2009. Well-wetted olivine grain boundaries 655 in partially molten peridotite in the asthenosphere. Earth Planet. Sci. Lett. 283, $656 \quad 167-173$.

657 Yu, H., Romanowicz, B., 2010. Lithospheric layering in the North American cra658 ton. Nature 466, 1063-1068. 